\title{
Is platelet-rich plasma an ideal biomaterial for arthroscopic rotator cuff repair? A systematic review and meta-analysis of randomized controlled trials
}

\author{
Changxu Han ${ }^{1 \dagger}$, Yuyan $\mathrm{Na}^{1 \dagger}$, Yong Zhu ${ }^{2}$, Lingyue Kong ${ }^{1}$, Tu Eerdun ${ }^{1}$, Xuejun Yang ${ }^{2^{*}}$ and Yizhong Ren ${ }^{1^{*}}$
}

\begin{abstract}
Background: Recently, many authors have reported the effects of platelet-rich plasma (PRP) on rotator cuff repair. Whether PRP treatment during arthroscopic rotator cuff repair improves tendon healing rates or restores full function remains unknown. The purpose of this meta-analysis was to evaluate the clinical improvement and radiological outcomes of PRP treatment in patients undergoing arthroscopic rotator cuff repair.

Methods: PubMed, EMBASE, and the Cochrane Central Register of Controlled Trials were searched. The study included only level 1 or 2 randomized controlled trials (RCTs) that compared the injection of platelet-rich plasma or platelet-rich fibrin matrix. The methodological quality of the trials was assessed using the Cochrane Handbook for Systematic Reviews of Interventions, 5.3. Continuous variables were analysed using the weighted mean difference, and categorical variables were assessed using relative risks. $P<0.05$ was considered statistically significant.

Results: The meta-analysis revealed a lower retear rate following PRP treatment than that following the control method (mean difference, 1.10; 95\% Cl, 1.03 to 1.18; $P=0.004$ ). Constant shoulder scores improved with PRP (mean difference, $2.31 ; 95 \% \mathrm{Cl}, 1.02$ to $3.61 ; P=0.0005$ ). PRP treatment also resulted in higher UCLA scores (mean difference, $0.98 ; 95 \% \mathrm{Cl}, 0.27$ to $1.69 ; P=0.007$ ), and simple shoulder test scores were improved (mean difference, $0.43 ; 95 \% \mathrm{Cl}, 0.11$ to $0.75 ; P=0.008$ ). Finally, lower visual analogue scale scores were observed with PRP augmentation (mean difference, $-0.35 ; 95 \% \mathrm{Cl},-0.57$ to $-0.13 ; P=0.002$ ).

Conclusions: The current systematic review and meta-analysis reveals that PRP treatment with arthroscopic repair of rotator cuff tears decreases the retear rate and improves the clinical outcomes.
\end{abstract}

Systematic review registration: PROSPERO CRD42016048416

Keywords: Platelet-rich plasma, Rotator cuff, Meta-analysis, Arthroscopic

\footnotetext{
*Correspondence: yanglaoshi2017@163.com; namedical@sina.com

${ }^{+}$Changxu Han and Yuyan Na contributed equally to this work.

${ }^{2}$ Department of Spinal Surgery, The Second Hospital of Inner Mongolia

Medical University, No. 1 Yingfang Street, Huimin District, Hohhot 010000,

Inner Mongolia Autonomous Region, China

'Department of Arthroscopy and Sports Medicine, The Second Affiliated

Hospital of Inner Mongolia Medical University, No. 1 Yingfang Street, Huimin

District, Hohhot 010000, Inner Mongolia Autonomous Region, China
}

(c) The Author(s). 2019 Open Access This article is distributed under the terms of the Creative Commons Attribution 4.0 International License (http://creativecommons.org/licenses/by/4.0/), which permits unrestricted use, distribution, and reproduction in any medium, provided you give appropriate credit to the original author(s) and the source, provide a link to the Creative Commons license, and indicate if changes were made. The Creative Commons Public Domain Dedication waiver (http://creativecommons.org/publicdomain/zero/1.0/) applies to the data made available in this article, unless otherwise stated. 


\section{Introduction}

The use of autologous platelet-rich plasma (PRP) or similar products containing platelets has been widely studied in bone and tendon tissue healing and reconstruction [1-5]. PRP is known to contain more than 1500 bioactive proteins that are important for tendon healing, including growth factors such as transforming growth factor beta (TGF-ß), fibroblast growth factor (FGF), and platelet-derived growth factor (PDGF) $[6,7]$.

PRP, glucocorticoids, local anaesthetics, or hyaluronic acid are used to reduce pain and improve performance in patients who undergo rotator cuff repair. Among them, local anaesthetics and glucocorticoids have cytotoxic effects on tenocytes, and hyaluronic acid decreases pain in patients with partial tear of the rotator cuff tendons [8]. Recently, many authors have reported the effects of PRP on partial or complete tears of rotator cuff tendons [9-11]. These trials returned mixed results [914] and were unable to show consistently improved retear rates or improved clinical outcome scores. Although some meta-analyses on this topic have been published [15-19], these have also returned mixed results. Whether PRP treatment during arthroscopic rotator cuff repair improves tendon healing rates or restores of full function remains unknown.

The aim of this study was to conduct a systematic review and meta-analysis of level I and level II studies to investigate the clinical and imaging outcomes of PRP treatment during arthroscopic repair of rotator cuff tears. Our hypothesis is that PRP application deceases retear rates and improves clinical outcomes.

\section{Literature search}

We searched the Cochrane Central Register of Controlled Trials (2016 Issue 2), EMBASE (1980 to 2016 Week 36), and PubMed (1946 to September 2016). No language restrictions were applied. Search terms were as follows: platelet-rich plasma OR plasma OR platelet-rich OR platelet gel OR platelet plasma OR PRP OR PRFM OR plateletrich fibrin matrix OR PRFM OR platelet AND rotator cuff OR supraspinatus tendon OR supraspinatus. The references of published studies were assessed by manual search to identify additional articles. Finally, we searched the following journal contents within the previous 5 years for randomized controlled trials: British Journal of Sports Medicine, the Journal of Shoulder and Elbow Surgery, Arthroscopy, The Journal of Arthroscopic and Related Surgery, and The American Journal of Sports Medicine.

\section{Eligibility criteria}

Inclusion criteria were as follows: studies of patients diagnosed with rotator cuff tears requiring arthroscopic repair; level I or II randomized controlled trials; studies in which the treatment group received an injection of platelet-rich plasma or platelet-rich fibrin matrix; studies with patients aged 18 years or older; studies with adequate statistical power to defect differences with $95 \%$ confidence intervals (CIs); studies with a minimum of one of the following outcome measurements performed postoperatively: American Shoulder and Elbow Surgeons (ASES) score, constant shoulder score, University of California at Los Angeles (UCLA) score, Simple Shoulder Test score, with radiography (MRI and/or USG); studies with patient follow-up $>80 \%$; studies with a minimum follow-up of 6 months; and studies with no restrictions on treatment dosage, usage of procedures, or number of injections.

The exclusion criteria were as follows: retrospective studies; case-control studies; case reports; studies without abstracts; level III or IV evidence studies; studies of patients with a history of previous injury or surgery to the same shoulder, with postoperative infection, with rheumatoid arthritis, or with arthrofibrosis; studies with inadequate follow-up; studies reporting outcomes only after PRP treatment; and studies including open or mini-open surgical procedures.

\section{Data extraction}

Extraction of all variables and outcomes of interest and assessment of methodological quality were performed independently by two authors (C-X.H. and Y-Y.N.). Reviewers were not blinded to the study authors, journal, or source of financial support. Disagreements were resolved through discussion and, when necessary, by consultation with a third author (Y-Z.R.). The following data/information were extracted from the studies that met the inclusion criteria: first author's name; publication year; percent of males; mean age; number of patients; population differences; repair type; PRP types; clinical and imaging followup intervals; clinical outcome scores; and the number of retears in each study group and control group.

\section{Assessment of methodological quality}

The methodological quality of the trials was assessed using the Cochrane Handbook for Systematic Reviews of Interventions, 5.3. To determine the possibility of bias, we examined random sequence generation, allocation concealment, blinding of patients and personnel, blinding of outcome assessment, incomplete outcome data, and selective reporting risk. Risk of bias figures were generated using Cochrane Review Manager software 5.3.

\section{Assessment of heterogeneity}

The heterogeneity of each study was assessed by two separate reviewers (C-X.H. and Y-Y.N.), based on the Cochrane Handbook for Systematic Reviews of Interventions [20]. Differences of opinion between reviewers were resolved by discussion and consultation with a 
third author (Y-Z.R.). Both clinical heterogeneity (e.g. differences among patients, interventions, and outcomes) and statistical heterogeneity (variation between trials in the underlying treatment effects being evaluated [21]) were considered. We assessed heterogeneity by visual inspection of the forest plots. To determine inconsistencies in the study results, statistical heterogeneity between studies was formally tested with a standard csquare test. We used the $I^{2}$ test to provide an objective measurement of statistical heterogeneity. According to the Cochrane Handbook [22], heterogeneity was quantified using the $I^{2}$ statistic with a rough guide for interpretation as follows: 0 to $40 \%$-no heterogeneity, 30 to $60 \%$-moderate heterogeneity, 50 to $90 \%$-substantial heterogeneity, and 75 to $100 \%$ - considerable heterogeneity. A fixed effects model was used if the $I^{2}$ values were less than 60\%; otherwise, a random effects model was used. Tests for significance were two-tailed, and $P<0.05$ was deemed significant.

\section{Subgroups and sensitivity}

Subgroup analyses and sensitivity values were used to assess factors responsible for potential heterogeneity. We were unable to perform all planned analyses due to the lack of data (see differences between protocol and review). Analyses were dependent on the number of studies included and the availability of appropriate outcomes and covariates. We further investigated heterogeneity by observing the effects of removing single trial outliers. If there was heterogeneity across studies, studies were categorized into various subgroups (e.g. tear size).

We performed sensitivity analyses (the leave-one-out approach) to evaluate the impact of removing from the analysis studies at high or unclear risk of selection bias (primarily in terms of inadequate allocation concealment) and those with detection bias (lack of assessor blinding).

\section{Statistical analysis}

Statistical analysis was performed using Review Manager 5.3 (Cochrane Collaboration, Nordic Cochrane Centre, Copenhagen, Denmark). Continuous variables were analysed using the weighted mean difference, and categorical variables were assessed using relative risks. $P<0.05$ was considered statistically significant, and 95\% CIs are reported. Homogeneity was tested by the $Q$ statistic (significance level at $P<0.1$ ) and the $I^{2}$ statistic (significance level at $\left.I^{2}>50 \%\right)$. A random effects model was used if the $Q$ or $I^{2}$ value was statistically significant; otherwise, a fixed effects model was used. In addition, only outcomes reported by four or more studies were pooled to ensure good validity and high quality. Fewer than four references created an excessive opportunity for bias [23]. If a study reported the preoperative baseline of an outcome (e.g. shoulder score) and it was not similar between the two groups, this outcome was not put into the pool in our meta-analysis.

\section{Results}

A flow diagram outlining the process for study selection is shown in Fig. 1. A total of 513 potentially relevant articles were identified after duplicates were removed.

After screening titles and abstracts, 390 records were eliminated, leaving 14 studies for further review. Fourteen articles [9, 24-35] met eligibility criteria. Two studies $[24,34]$ were derived from the same randomized controlled trial. The follow-up times of these two studies were different ( 1 and 2 years). We extracted data from the article reporting the 1-year follow-up [34] to ensure a similar time of outcome assessment with other included studies.

\section{Study characteristics}

The principal study characteristics are displayed in Table 1. A total of 880 patients (439 in the PRP application groups and 441 in the control groups) were included, with individual sample sizes ranging from 28 to 88 patients. The patient age range was 29 to 77 years. The gender distribution between the two groups was similar. The final follow-up was 6 to 16 months posttreatment. Table 2 displays the distinctive characteristics of each study, including tear type, rotator cuff repair techniques, method of PRP preparation, subjective outcomes, and relevant findings. In addition, the PRP type and injection characteristics of the included studies are listed in Table 3. Besides, PRP type and injection characteristics of the included studies are listed in Table 3.

\section{Risk of bias assessment of the randomized controlled trials (RCTs)}

All included studies reported the level of evidence in the publication itself (therapeutic level I in 11 studies $[9,10$, 25-31, 33, 35] and therapeutic level II in two studies $[32,34])$. The risk of bias assessed by the Cochrane Collaboration's tool for qualitative parts is shown in Fig. 2. The studies had a low to medium risk of bias. A risk of bias was found in four of 13 studies (30.2\%) due to randomization procedures (allocation concealment bias $[9,27,28,35])$ and in five of $13(38.5 \%)$ studies [28, 30$32,34]$ related to performance bias. In seven of 13 studies $(45.5 \%)$, the completeness of randomization procedures (selection bias) was unclear, either because of the absence of a Consolidated Standards of Reporting Trials statement or because of the absence of an intention-totreat analysis [10, 26, 27, 30, 31, 33, 34]. 


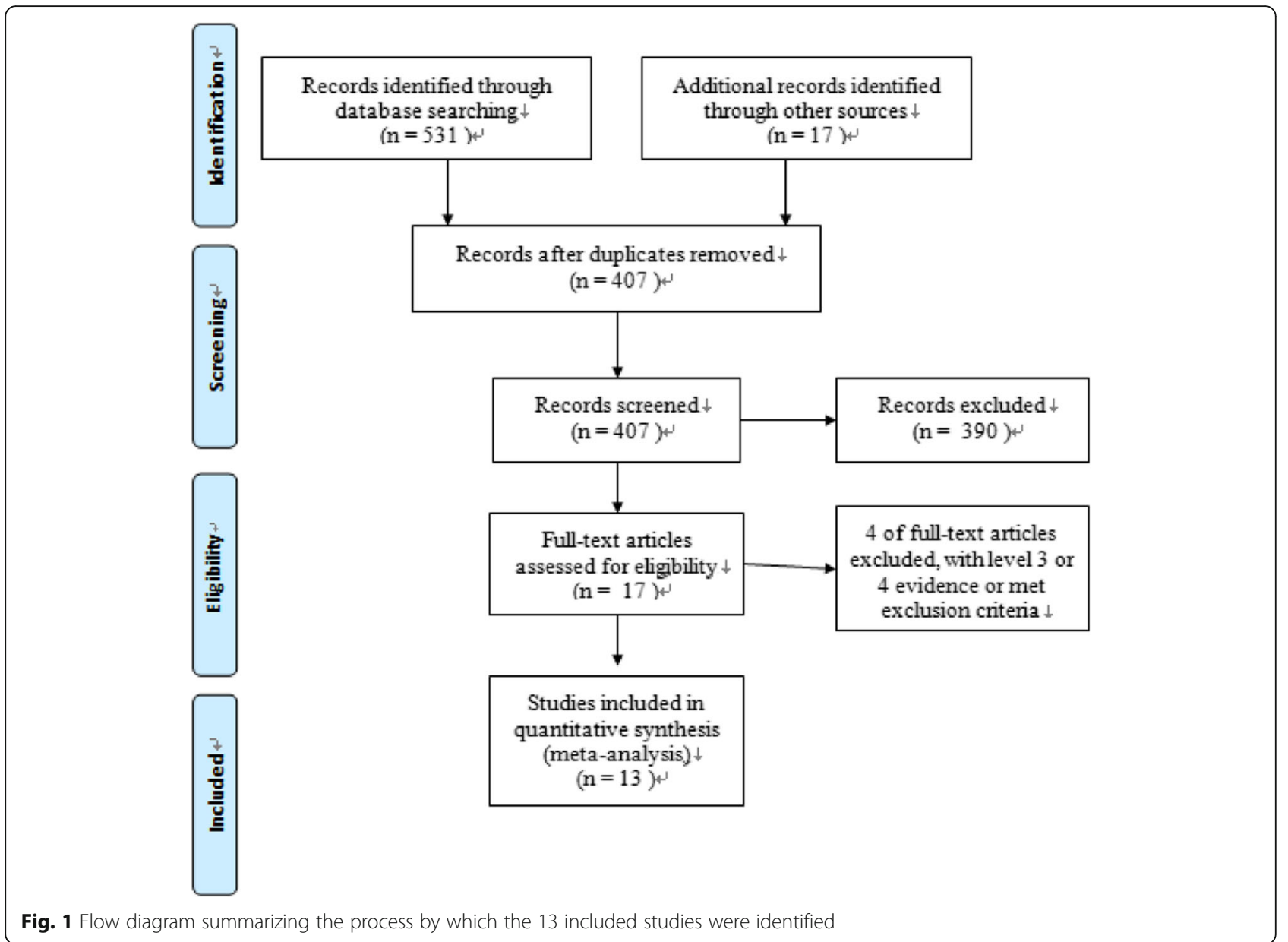

Table 1 Characteristics of included randomized controlled trials. PRP platelet-rich plasma

\begin{tabular}{|c|c|c|c|c|c|c|}
\hline Authors & $\begin{array}{l}\text { Publish } \\
\text { year }\end{array}$ & $\begin{array}{l}\text { Male \% (PRP+/ } \\
\text { PRP-) }\end{array}$ & $\begin{array}{l}\text { Mean age } \\
(\mathrm{PRP}+/ \mathrm{PRP}-)\end{array}$ & $\begin{array}{l}\text { Shoulders analysed } \\
\text { (PRP+/PRP-) }\end{array}$ & $\begin{array}{l}\text { Minimum imaging follow- } \\
\text { up, months }\end{array}$ & $\begin{array}{l}\text { Minimum clinical follow- } \\
\text { up, months }\end{array}$ \\
\hline Castricini et al. [25] & 2011 & $40(17 / 23)$ & $(55.5 / 55.2)$ & $88(43 / 45)$ & 16 & 16 \\
\hline Randelli et al. [31] & 2011 & $21(8 / 13)$ & $(61.3 / 59.5)$ & $45(22 / 23)$ & 12 & 12 \\
\hline Gumina et al. [27] & 2012 & $41(20 / 21)$ & $61(60 / 63)$ & $76(39 / 37)$ & 12 & 12 \\
\hline Weber et al. [35] & 2012 & $36(20 / 16)$ & $(59.7 / 64.5)$ & $59(29 / 30)$ & 12 & 12 \\
\hline Jo et al. [28] & 2013 & $24(10 / 14)$ & $(64.2 / 61.9)$ & $47(24 / 23)$ & 9 & 12 \\
\hline $\begin{array}{l}\text { Ruiz-Moneo et al. } \\
\text { [33] }\end{array}$ & 2013 & $25(14 / 11)$ & $(56 / 55)$ & $63(32 / 31)$ & 12 & 12 \\
\hline Malavolta et al. [30] & 2014 & $17(8 / 9)$ & $(55.3 / 54.1)$ & $54(27 / 27)$ & 12 & 12 \\
\hline $\begin{array}{l}\text { Sánchez Márquez et } \\
\text { al. [34] }\end{array}$ & 2011 & 8 (NR/NR) & 65 (NR/NR) & $28(14 / 14)$ & 12 & 12 \\
\hline Rodeo et al. [32] & 2012 & $44(23 / 21)$ & $(58.9 / 57.2)$ & $67(35 / 32)$ & 3 & 12 \\
\hline Flury et al. [26] & 2016 & $38(18 / 20)$ & $58.9 / 57.8$ & $103(49 / 54)$ & 24 & 24 \\
\hline Holtby et al. [9] & 2016 & $41(20 / 21)$ & $59 / 59$ & $74(36 / 38)$ & 6 & 6 \\
\hline Pandey et al. [10] & 2016 & $74(38 / 36)$ & $54.8 / 54.1$ & $102(52 / 50)$ & $24(12)$ & $24(12)$ \\
\hline Jo et al. [29] & 2015 & $17(8 / 9)$ & $60.8 / 60.92$ & $74(37 / 37)$ & 12 & 12 \\
\hline
\end{tabular}


Table 2 Summary of included randomized controlled trial

\begin{tabular}{|c|c|c|c|c|}
\hline $\begin{array}{l}\text { Authors/publish } \\
\text { year }\end{array}$ & Population differences & Repair type & Outcomes measured & Relevant findings \\
\hline $\begin{array}{l}\text { Castricini et al. } \\
2011[25]\end{array}$ & $\begin{array}{l}\text { Included any full-thickness } \\
\text { tear }\end{array}$ & Double row & $\begin{array}{l}\text { Subjective: Constant scores } \\
\text { Imaging: MRI at } 16 \text { months }\end{array}$ & No difference in constant scores and retear rates between groups \\
\hline $\begin{array}{l}\text { Randelli et al. } \\
2011[31]\end{array}$ & $\begin{array}{l}\text { Included any full-thickness } \\
\text { tear }\end{array}$ & Single row & $\begin{array}{l}\text { Subjective: Constant, UCLA, SST } \\
\text { Imaging: MRI } 12 \text { months }\end{array}$ & $\begin{array}{l}\text { Significant improvement in constant, UCLA, and SST in PRPp group } \\
\text { No difference in outcomes at final follow-up }\end{array}$ \\
\hline $\begin{array}{l}\text { Gumina et al. } \\
2012[27]\end{array}$ & $\begin{array}{l}\text { Included only large tears } \\
\text { Excluded partial tears, } \\
\text { massive tears, traumatic } \\
\text { tears }\end{array}$ & Single row & $\begin{array}{l}\text { Subjective: Constant, ST } \\
\text { Imaging: MRI at } 12 \text { months }\end{array}$ & $\begin{array}{l}\text { Significantly increased constant score in the PRPp group, but no } \\
\text { difference in change from pre- to postoperatively }\end{array}$ \\
\hline $\begin{array}{l}\text { Weber et al. } \\
2012[35]\end{array}$ & $\begin{array}{l}\text { Included any arthroscopic } \\
\text { rotator cuff repair }\end{array}$ & Single row & $\begin{array}{l}\text { Subjective: ASES, UCLA, SST, } \\
\text { VAS } \\
\text { Imaging: MRI at } 12 \text { months } \\
\text { ROM }\end{array}$ & $\begin{array}{l}\text { No difference in outcome scores or ROM between groups } \\
\text { No difference in retear rates between groups }\end{array}$ \\
\hline $\begin{array}{l}\text { Jo et al. } 2013 \\
{[28]}\end{array}$ & $\begin{array}{l}\text { Included only large tears (> } \\
3 \mathrm{~cm} \text { sagittal length) } \\
\text { Included } 4 \text { partial repairs }\end{array}$ & Double row & $\begin{array}{l}\text { Subjective: ASES, CLA, Constant, } \\
\text { SST, DASH, SPADI } \\
\text { Imaging: MRI or CTA at } \\
9 \text { months }\end{array}$ & $\begin{array}{l}\text { No difference between the two groups on the VAS for pain, ROM, } \\
\text { muscle strength, overall satisfaction, and function } \\
\text { The retear rate of the PRP group was significantly lower }\end{array}$ \\
\hline $\begin{array}{l}\text { Ruiz-Moneo et } \\
\text { al. } 2013 \text { [33] }\end{array}$ & $\begin{array}{l}\text { Included tendon retraction } \\
\text { and fatty infiltration, smokers }\end{array}$ & Double row & $\begin{array}{l}\text { Subjective: UCLA } \\
\text { Imaging: MRA at } 12 \text { months }\end{array}$ & $\begin{array}{l}\text { No difference in UCLA scores between groups } \\
\text { No difference in retear rates between groups }\end{array}$ \\
\hline $\begin{array}{l}\text { Malavolta et al. } \\
2014[30]\end{array}$ & $\begin{array}{l}\text { Included only tears }<3 \mathrm{~cm} \\
\text { in sagittal length }\end{array}$ & Single row & $\begin{array}{l}\text { Subjective: Constant, UCLA } \\
\text { Imaging: MRI at 3, 6, and } \\
12 \text { months }\end{array}$ & $\begin{array}{l}\text { No differences in constant or UCLA scores between groups } \\
\text { No difference in retear rates between groups }\end{array}$ \\
\hline $\begin{array}{l}\text { Sánchez } \\
\text { Márquez et al. } \\
2011[34]\end{array}$ & $\begin{array}{l}\text { Included only repairable } \\
\text { large tears }>5 \\
\text { Excluded subscapularis tears }\end{array}$ & Single row & $\begin{array}{l}\text { Subjective: Constant } \\
\text { Imaging: MRA at } 12 \text { months }\end{array}$ & $\begin{array}{l}\text { No differences in constant or UCLA scores between groups } \\
\text { No difference in retear rates between groups }\end{array}$ \\
\hline $\begin{array}{l}\text { Rodeo et al. } \\
2012[32]\end{array}$ & $\begin{array}{l}\text { Included full-thickness tears, } \\
\text { age }>40 \text { years }\end{array}$ & Double row & $\begin{array}{l}\text { Subjective: ASES, L'Insalata } \\
\text { Imaging: US at } 12 \text { weeks }\end{array}$ & $\begin{array}{l}\text { No difference in outcome scores between groups } \\
\text { No difference in retear rates between groups }\end{array}$ \\
\hline $\begin{array}{l}\text { Flury et al. } 2016 \\
\text { [26] }\end{array}$ & A complete rotator cuff tear & Double row & $\begin{array}{l}\text { Subjective: Constant-Murley } \\
\text { score, ASES, OSS } \\
\text { Imaging: MRI or US at } \\
12 \text { months }\end{array}$ & $\begin{array}{l}\text { No significantly improved function at } 3,6 \text {, and } 24 \text { months after } \\
\text { arthroscopic repair compared with control patients receiving } \\
\text { ropivacaine }\end{array}$ \\
\hline $\begin{array}{l}\text { Holtby et al. } \\
2016[9]\end{array}$ & $\begin{array}{l}\text { Full-thickness and partial- } \\
\text { thickness tear }\end{array}$ & $\begin{array}{l}\text { Single row } \\
\text { and double } \\
\text { row }\end{array}$ & $\begin{array}{l}\text { Subjective: VAS, CMS, ASES, } \\
\text { ShortWORC } \\
\text { Imaging: MRI at } 6 \text { months }\end{array}$ & $\begin{array}{l}\text { A short-term effect on perioperative pain } \\
\text { No significant impact on patient-oriented outcome measures or } \\
\text { retear rate }\end{array}$ \\
\hline $\begin{array}{l}\text { Pandey et al. } \\
2016[10]\end{array}$ & $\begin{array}{l}\text { Medium-sized to large cuff } \\
\text { tears }\end{array}$ & Single row & $\begin{array}{l}\text { Subjective: VAS, CMS, ASES, } \\
\text { UCLA } \\
\text { Imaging: US at } 24 \text { months }\end{array}$ & $\begin{array}{l}\text { Retear in the PRP group was significantly lower, significant } \\
\text { improvement in constant, UCLA score } \\
\text { No difference in ASES score }\end{array}$ \\
\hline $\begin{array}{l}\text { Jo et al. } 2015 \\
{[29]}\end{array}$ & $\begin{array}{l}\text { Medium to large rotator cuff } \\
\text { tears }\end{array}$ & Double row & $\begin{array}{l}\text { Subjective: Constant score, VAS, } \\
\text { ASES, UCLA, SST, SPADI scores } \\
\text { Imaging: MRI at } 12 \text { months }\end{array}$ & $\begin{array}{l}\text { A decreased retear rate of the supraspinatus, but not the speed of } \\
\text { healing } \\
\text { No significantly improved function scores at and } 12 \text { months after } \\
\text { arthroscopic }\end{array}$ \\
\hline
\end{tabular}

Table 3 PRP type and injection characteristics

\begin{tabular}{lllll}
\hline Study & Leukocyte-poor/rich PRP & Volume $(\mathrm{ml})$ & Activating agent & Applied site \\
\hline Castricini et al. 2011 [25] & Leukocyte-rich PRP & NR & Not report & Bone-tendon interface \\
Randelli et al. 2011 [31] & Leukocyte-rich PRP & 6 & Calcium chloride & Bone-tendon interface and subacromial space \\
Gumina et al. 2012 [27] & Leukocyte-rich PRP & 5.2 & Calcium gluconate & Bone-tendon interface \\
Weber et al. 2012 [35] & Leukocyte-poor PRP & 1 & Calcium & Bone-tendon interface \\
Jo et al. 2013 [28] & Leukocyte-poor PRP & 9 & Calcium gluconate & Bone-tendon interface \\
Ruiz-Moneo et al. 2013 [33] & Leukocyte-poor PRP & 1 & Calcium chloride & Bone-tendon interface \\
Malavolta et al. 2014 [30] & Leukocyte-poor PRP & 10 & Calcium chloride & Bone-tendon interface \\
Sánchez Márquez et al. 2011 [34] & Leukocyte-poor PRP & 7 & Not report & Bone-tendon interface \\
Rodeo et al. 2012 [32] & Leukocyte-poor PRP & 9 & Calcium chloride & Bone-tendon interface \\
Flury et al. 2016 [26] & Leukocyte-poor PRP & 4 & Not report & Bone-tendon interface \\
Holtby et al. 2016 [9] & Leukocyte-poor PRP & 7 & Not report & Bone-tendon interface \\
Pandey et al. 2016 [10] & Leukocyte-poor PRP & 8 & Calcium chloride & Bone-tendon interface \\
Jo et al. 2015 [29] & Leukocyte-poor PRP & 9 & Calcium gluconate & Bone-tendon interface \\
\hline
\end{tabular}




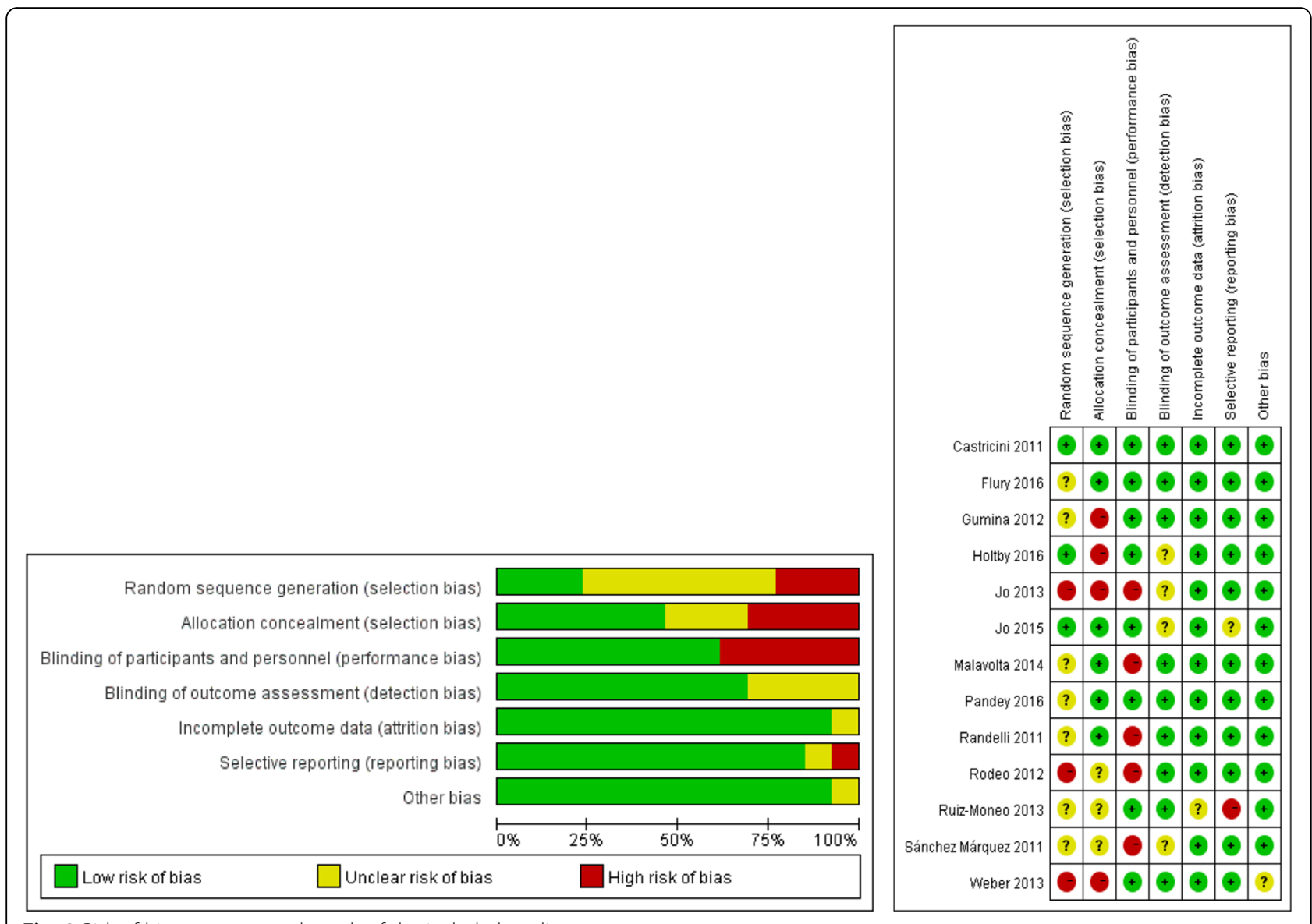

Fig. 2 Risk of bias summary and graph of the included studies

\section{Retear rate}

Twelve randomized controlled trials with a total of 773 patients reported a retear rate at the last follow-up ([9, 10, 25-31, 33-35], Fig. 3). Retears occurred in 63 (16\%) of 392 patients in the platelet-rich plasma group and in $90(24 \%)$ of 381 patients in the control group (mean difference, $1.10,95 \% \mathrm{CI}, 1.03$ to $1.18, P=0.004$, Fig. 3 ). The integrity of the repaired rotator cuff was evaluated by magnetic resonance imaging (MRI) in several studies [9, 25, 27, 29-31, 33-35]. MRI or computed tomographic arthrography was reported in one study [28], MRI or ultrasonography in one study [26], and

\begin{tabular}{|c|c|c|c|c|c|c|c|}
\hline Studv or Subgr oup & \multicolumn{2}{|c|}{ with PRP } & \multicolumn{2}{|c|}{ without PRP } & Weight & $\begin{array}{l}\text { Risk Ratio (Non-event) } \\
\text { M-H, Fixed, 95\% Cl }\end{array}$ & $\begin{array}{c}\text { Risk Ratio (Non-event) } \\
\text { M-H, Fixed, 95\% Cl }\end{array}$ \\
\hline Castricini 2011 & 1 & 40 & 4 & 38 & $11.8 \%$ & $1.09[0.97,1.23]$ & $t=$ \\
\hline Flury 2016 & 5 & 49 & g & 54 & $14.5 \%$ & $1.08[0.93,1.25]$ & $=$ \\
\hline Gumina 2012 & 0 & 39 & 3 & 37 & $12.0 \%$ & $1.09[0.98,1.21]$ & - \\
\hline Holtby 2016 & 5 & 36 & 7 & 38 & $10.2 \%$ & $1.06[0.86,1.29]$ & - \\
\hline Jo 2013 & 4 & 20 & 10 & 18 & $2.9 \%$ & $1.80[1.03,3.15]$ & \\
\hline Jo 2015 & 1 & 33 & 6 & 30 & $8.5 \%$ & $1.21[1.00,1.46]$ & $\rightarrow$ \\
\hline Malavolta 2014 & 2 & 27 & 5 & 27 & $7.5 \%$ & $1.14[0.92,1.40]$ & - \\
\hline Pandey 2016 & 2 & 52 & 10 & 50 & $13.8 \%$ & $1.20[1.04,1.39]$ & $\rightarrow$ \\
\hline Randelli 2011 & 9 & 22 & 12 & 23 & $3.6 \%$ & $1.24[0.71,2.14]$ & \\
\hline Ruiz-Maneo 2013 & 13 & 32 & 11 & 28 & $6.2 \%$ & $0.98[0.65,1.48]$ & \\
\hline Sánchez Márquez 2011 & 9 & 14 & 6 & 14 & $2.7 \%$ & $0.63[0.27,1.44]$ & \\
\hline Weber 2013 & 12 & 28 & 7 & 24 & $6.2 \%$ & $0.81[0.53,1.22]$ & - \\
\hline Total $(95 \% \mathrm{Cl})$ & & 392 & & 381 & $100.0 \%$ & $1.10[1.03,1.18]$ & $\bullet$ \\
\hline Total events & 63 & & 90 & & & & \\
\hline $\begin{array}{l}\text { Heterogeneity: } \mathrm{Chi}^{2}=10 \\
\text { Test for overall effect: } Z\end{array}$ & $\begin{array}{l}2, d f=11 \\
2.86(P=0\end{array}$ & $\begin{array}{l}(P=0 \\
0.004)\end{array}$ & .52); $F^{2}=0$ & & & & 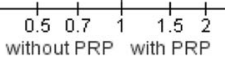 \\
\hline
\end{tabular}

Fig. 3 Forest plot for retear rate. A fixed-effects model was used because of the acceptable heterogeneity $(I 2=0 \%)$. The size of each square is proportional to the weight of the study. The dark diamond on the right of the vertical line, indicating that the retear rate was lower after PRP application than control groups. (Cl, confidence interval; df, degrees of freedom; 12 , heterogeneity test; $\mathrm{M}-\mathrm{H}$, Mantel-Haenszel; PRP, platelet-rich plasma; $z$, P value of weighted test for overall effect) 
ultrasonography in one study [10]. The test for heterogeneity showed no significant heterogeneity of the pooled results $\left(I^{2}=0 \% ; P=0.52\right)$. No further analysis was possible.

\section{Constant score}

Constant shoulder scores at the last follow-up were reported for 615 patients in nine studies [10, 25-31, 34], Fig. 4). Significant differences were found in the fixed effects model between the PRP+ and PRP- treatment groups at the last follow-up along their respective recovery paths $(P=0.0005)$. These data suggest that constant shoulder score improvement may be accelerated by PRP treatment in arthroscopic repair of rotator cuff tears (mean difference, 2.31; 95\% CI, 1.02 to 3.61; $P=0.0005$, Fig. 4). No statistical heterogeneity was found $\left(I^{2}=0 \%\right.$; $P=0.43)$. No further analysis was possible.

\section{University of California at Los Angeles (UCLA) score}

Seven trials $[10,28-31,33,35]$ with a total of 444 patients reported UCLA score outcomes at the end of follow-up (Fig. 5). The pooled data in the fixed effects analysis showed a significantly higher UCLA score with PRP treatment (mean difference, $0.98 ; 95 \% \mathrm{CI}, 0.27$ to 1.69; $P=0.007$, Fig. 5). Heterogeneity across the studies was moderate $\left(P=0.08 ; I^{2}=47 \%\right)$.

\section{American Shoulder and Elbow Surgeons (ASES) score}

Seven studies with a total of 503 patients available at the latest follow-up reported ASES scores (Fig. 6). Fixedeffects analysis showed that the difference was not significant between the two groups (mean difference, 0.90; $95 \% \mathrm{CI},-0.77$ to $2.57 ; P=0.23$, Fig. 6 ). No significant heterogeneity was found $\left(I^{2}=26 \% ; P=0.23\right)$. No further analysis was possible.

\section{Simple Shoulder Test (SST) score}

Four studies [27-29, 31] with a total of 251 patients available at the latest follow-up reported data on SST scores (Fig. 7). The forest plot showed significantly higher SST scores with PRP augmentation (mean difference, $0.43 ; 95 \% \mathrm{CI}, 0.11$ to $0.75 ; P=0.008$, Fig. 7 ). No statistical heterogeneity was found $\left(I^{2}=0 \% ; P=0.99\right)$. No further analysis was possible.

\section{Visual analogue scale (VAS) pain scores}

Five of the 13 studies [10, 28-31] provided complete data regarding visual analogue scale pain scores at preand post-treatment. Five studies with a total of 331 patients with available data at the latest follow-up reported VAS scores (Fig. 8). The forest plot showed significantly lower VAS scores with PRP treatment (mean difference, -0.35 ; $95 \% \mathrm{CI},-0.57$ to $-0.13 ; P=0.002$ ). No statistical heterogeneity was found $\left(I^{2}=0 \% ; P=0.95\right)$. No further analysis was possible.

\section{Discussion}

Rotator cuff tears occur as a result of normal ageing, excessive loading, and microtrauma. They are common in the general population and can have serious effects on a person's work and life [36-38]. Several therapies have been reported; however, the problem can be difficult to manage. Thus, attention has turned to novel treatments [37, 39]. PRP has been investigated for its biological effects on the human rotator cuff $[40,41]$. However, the available evidence to support treatment is inadequate and even conflicting. Thus, we conducted this metaanalysis of 13 RCTs to compare the efficacy of plateletrich plasma or platelet-rich fibrin matrix application in conjunction with arthroscopic rotator cuff repair.

This meta-analysis of level I and level II studies examined the efficacy of PRP therapy in arthroscopic rotator cuff repairs. The main findings of the current study were that the use of PRP in rotator cuff repair had a significantly positive effect on postoperative retear rates and on functional outcome measures, including constant shoulder scores, constant pain scores, UCLA shoulder scores, and VAS scores. These results supported our

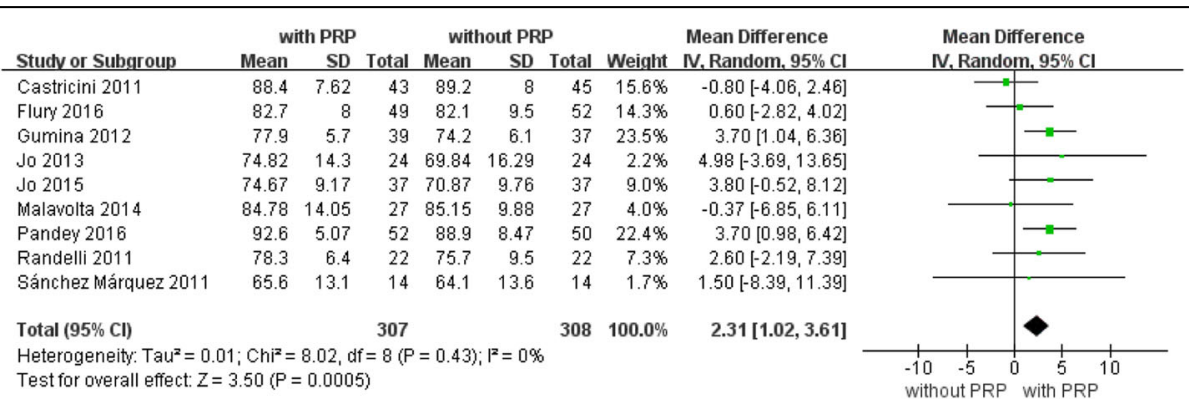

Fig. 4 Forest plot for Constant shoulder score. A fixed-effects model was used because of no heterogeneity $(I 2=0 \%)$. The size of each square is proportional to the weight of the study. The dark diamond on the right of the vertical line, indicating that the Constant Score was higher after PRP application than control groups. (Cl, confidence interval; df, degrees of freedom; I2, heterogeneity test; IV, inverse variance; PRP, platelet-rich plasma; SD, standard deviation; Z, P value of weighted test for overall effect) 


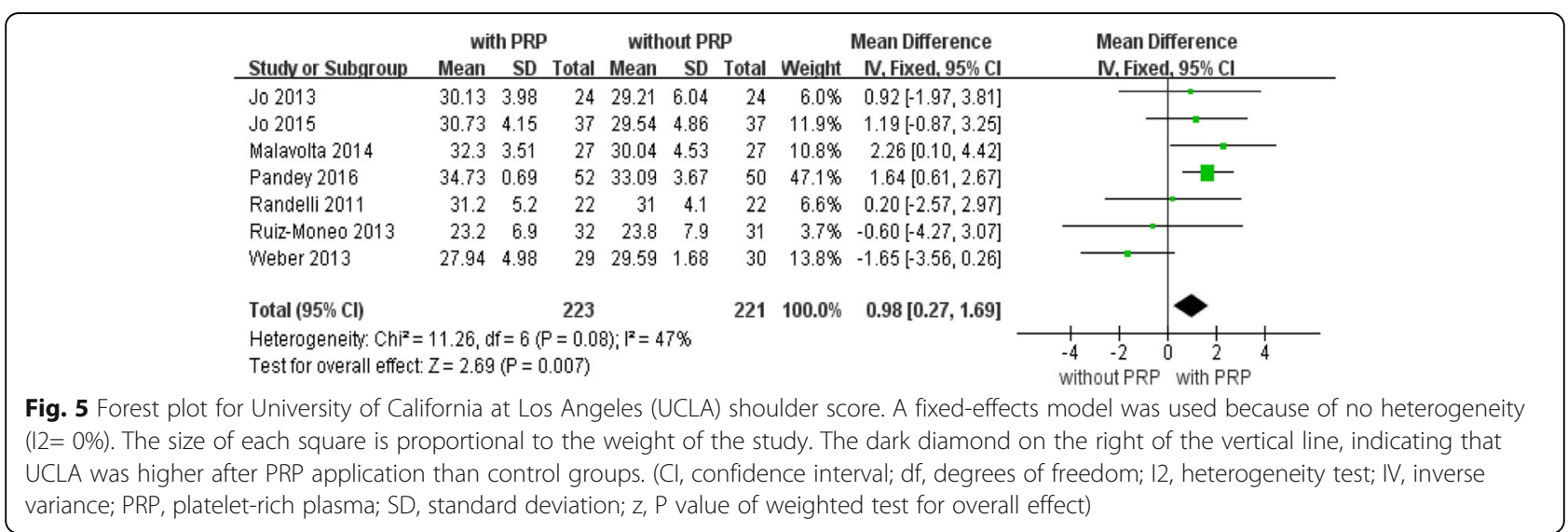

primary hypothesis that platelet-rich plasma deceases retear rates and improves functional outcomes following arthroscopic rotator cuff repair.

As a potential biological product, PRP has been widely used to promote the healing of bones, cartilage, and tendons [42-47]. PRP is rich in soluble growth factors that may be involved in tissue regeneration [48, 49]. When these growth factors are released from platelets, they trigger tissue regeneration [50-52]. Some animal studies have shown beneficial effects on the initial stage of rotator cuff tendon-to-bone healing following PRP treatment [53-55]. Hapa et al. [55] found that local autologous platelet-rich plasma injection may have beneficial effects on initial rotator cuff tendon-to-bone healing and may enhance initial tendon-to-bone healing remodelling in vivo. Beck et al. [53] reported that PRP and platelet-rich fibrin matrix significantly improved tendon-to-bone healing of repaired rat supraspinatus tears. In addition, PRP is being investigated for its biological effects on the human rotator cuff. Randelli et al. [11] first reported an uncontrolled pilot study of arthroscopic rotator cuff repair with PRP leading to improved pain and functional outcomes without any adverse events. Pandey et al. [10] found superior structural healing of arthroscopic repair of the large rotator cuff tears when treated with moderately concentrated PRP. PRP also accelerated the vascularity of the rotator cuff and surrounding tissues in the early healing phase. However, Holtby et al. [9] reported a prospective, double-blinded randomized controlled trial of arthroscopic rotator cuff repair with PRP showing improved short-term effects on perioperative pain without any significant impact on patient-oriented outcome measures or on structural integrity of the repair.

Although several meta-analyses evaluated the outcomes of arthroscopic rotator cuff surgery with PRP, these studies returned mixed results $[16-19,56,57]$. The routine use of PRP for arthroscopic rotator cuff repair is not warranted on the basis of these metaanalyses, as they have been unable to show any overall clinical superiority versus the control repair regimen. Whether PRP was the variable that improved function and rotator cuff healing remains unclear. Recently, several randomized controlled trials have been published on this topic $[10,26,29]$, affording the opportunity to perform a new meta-analysis to help resolve this controversy.

The benefit of our meta-analysis is that we pooled the data to more powerfully estimate the effect of PRP in

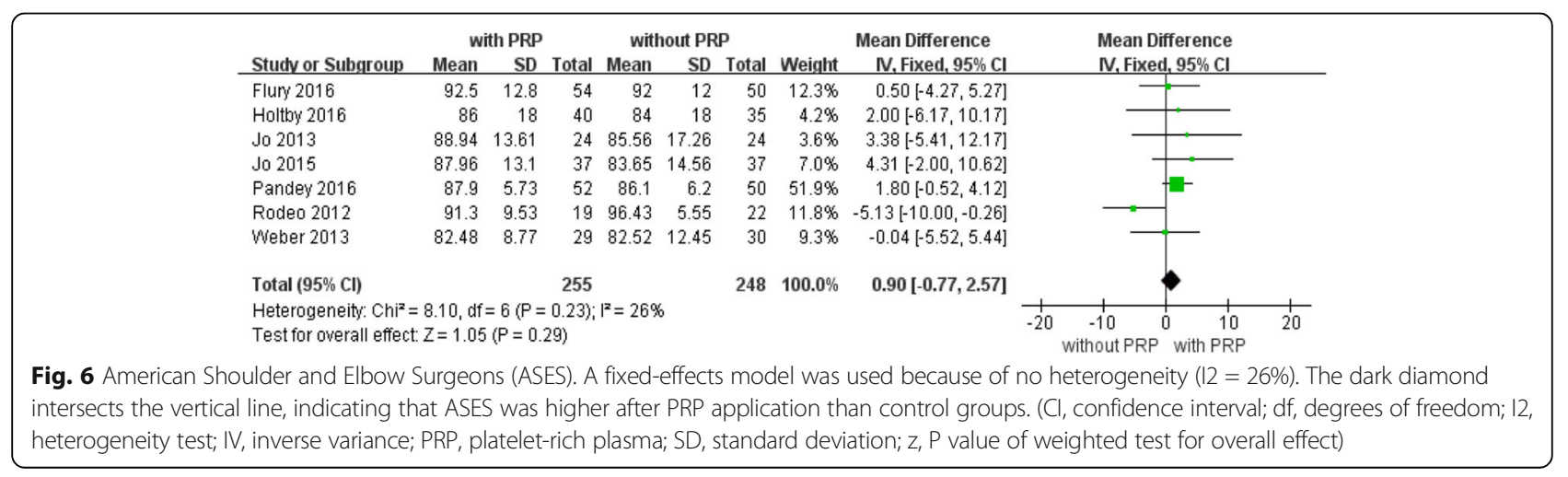




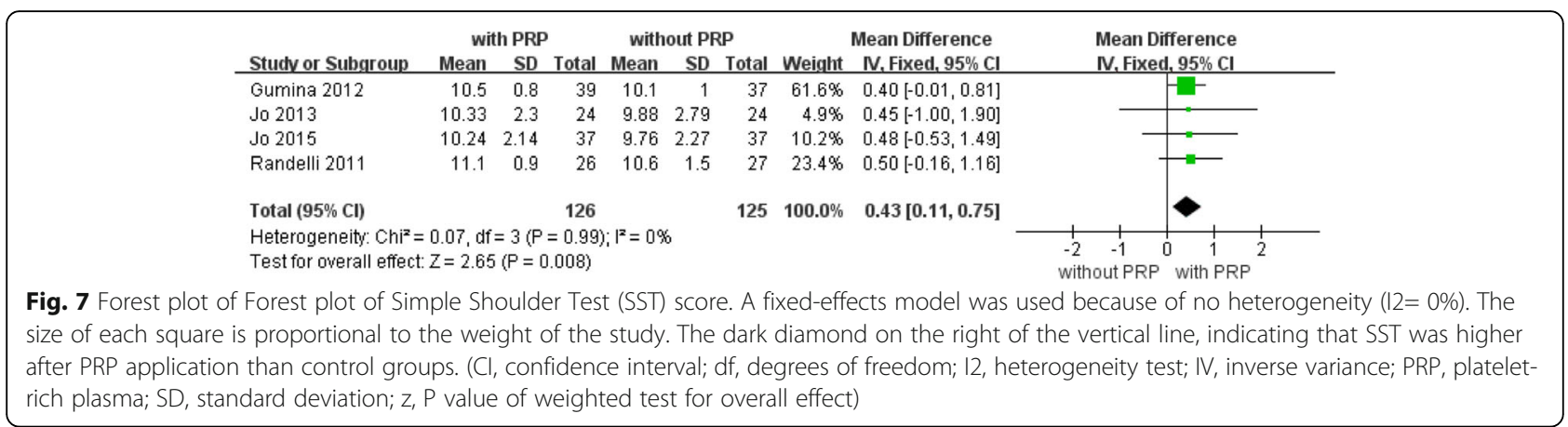

arthroscopic rotator cuff repair. We pooled 13 randomized controlled trials, showing that PRP decreases retear rates and most clinical outcomes, including constant shoulder scores, constant pain scores, UCLA shoulder scores, and SST scores.

Chahal et al. [58] performed a meta-analysis including various study types, such as randomized controlled trials, cohort studies, and case-control trials, although only two randomized controlled trials were included. Another meta-analysis performed by Zhang et al. [18] omitted a high-quality randomized controlled trial [33] and included one nonrandomized controlled trial. In a metaanalysis including five studies performed by Cai et al. [56], only level I evidence studies were considered. This may have increased the likelihood of selection bias. Zhao et al. [19] included eight randomized controlled trials and concluded that PRP gives similar retear rates and clinical outcomes as the control repair method does. However, one study included in their data only reported on the retear rate at 3 months, which was distinct from that reported in other studies. Fu et al. [57] evaluated a total of 11 studies in a meta-analysis, eight of which included patients with full-thickness rotator cuff tears. Functional score data were included in the subgroup analyses. Overall, the standard difference in means of the functional scores was similar between patients who were administered PRP/fibrin matrix and patients in the control group. Warth et al. [17] included 11 studies in their meta-analysis and reported overall similar outcome scores and retear rates between patients who received PRP and those who did not. However, they found that when the initial tear size was greater than $3 \mathrm{~cm}$ in the anterior-posterior length, the PRP group had decreased retear rates after double-row repairs $(25.9 \%$ vs. $57.1 \%$; $P=0.046)$.

The present analysis included more randomized controlled trials using a more extensive and updated search. The enlarged sample size provides more accurate estimates of the effects of PRP on rotator cuff repair.

\section{Limitations}

This meta-analysis has several limitations. First, this study possesses the potential for selection bias, performance bias, detection bias, attrition bias, and reporting bias, as is the case with any meta-analysis. Therefore, we conducted a thorough risk-of-bias assessment and presented the results in Fig. 2 to aid in data interpretation. Second, tear size may affect the differences between the two groups. No adequate studies report the outcomes of subgroups classified by tear size. Therefore, to ensure the rationality and validity of our meta-analysis, we did not perform subgroup analysis based on tear size. Third, some functional scores, such as the constant shoulder score, have not been specifically validated for use in

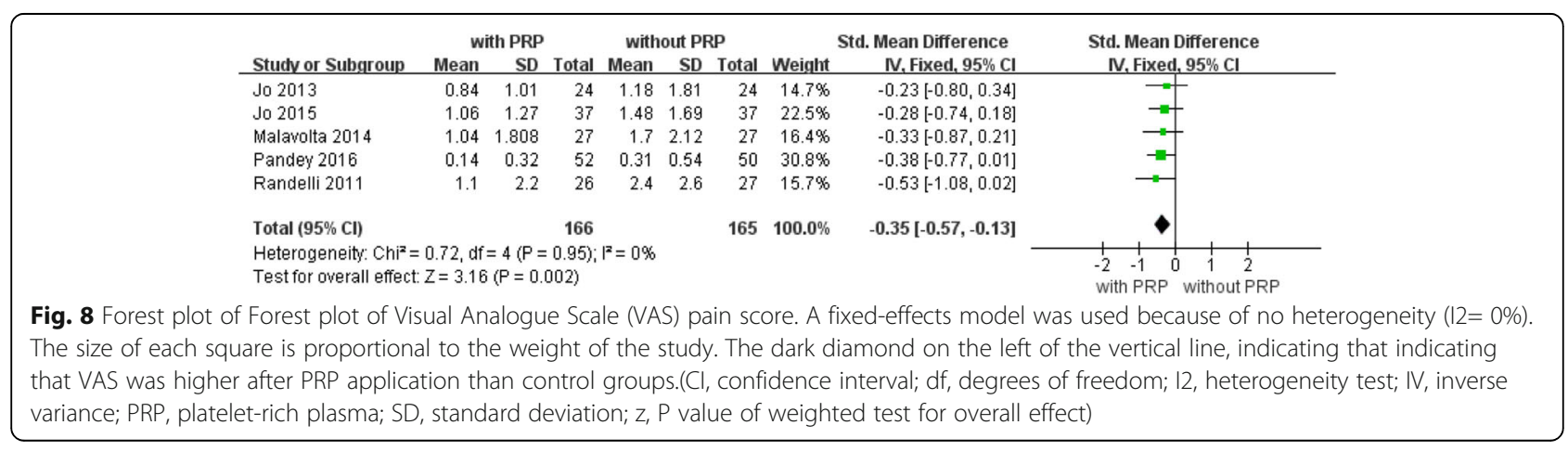


rotator cuff outcome studies. However, the score has been widely used in the literature and may well be appropriate for the rotator cuff literature.

\section{Conclusions}

Our systematic review and meta-analysis supports the use of PRP in the arthroscopic repair of rotator cuff tears. PRP may decrease retear rates and improve the clinical outcomes of arthroscopic rotator cuff repair.

\section{Abbreviations}

ASES: American Shoulder and Elbow Surgeons; Cls: Confidence intervals; PRP: Platelet-rich plasma; RCTs: Randomized controlled trials; SST: Simple shoulder test; UCLA: University of California at Los Angeles; VAS: Visual analogue scale

\section{Acknowledgements}

We are grateful to all the patients and surgeons of the included studies. We thank the native English-speaking scientists of Elixigen Company (Huntington Beach, CA, USA) for editing the manuscript.

\section{Authors' contributions}

$\mathrm{CH}, \mathrm{YR}$, and $\mathrm{XY}$ conceived and designed the study. $\mathrm{CH}, \mathrm{YN}$, and LK performed the search, extraction of data, and methodological assessment. $\mathrm{CH}, \mathrm{YN}, \mathrm{YZ}$, and TE analysed the data and wrote the paper. All authors read and approved the final manuscript.

\section{Funding}

This review was not supported by any specific grant from funding agencies in the public, commercial, or not-for-profit sectors.

\section{Availability of data and materials}

All data generated or analysed during this study are included in this published article.

\section{Ethics approval and consent to participate}

Not applicable.

\section{Consent for publication}

All authors read the final manuscript and approved for publication.

\section{Competing interests}

The authors declare that they have no competing interests.

Received: 1 March 2019 Accepted: 20 May 2019

Published online: 20 June 2019

\section{References}

1. Bava ED, Barber FA. Platelet-rich plasma products in sports medicine. Phys Sportsmed. 2011;39(3):94-9.

2. Beitzel K, Allen D, Apostolakos J, Russell RP, McCarthy MB, Gallo GJ, Cote MP, Mazzocca AD. US definitions, current use, and FDA stance on use of platelet-rich plasma in sports medicine. J Knee Surg. 2015;28(1):29-34.

3. Bielecki T, Dohan Ehrenfest DM. Platelet-rich plasma (PRP) and platelet-rich fibrin (PRF): surgical adjuvants, preparations for in situ regenerative medicine and tools for tissue engineering. Curr Pharm Biotechnol. 2012; 13(7):1121-30

4. Mishra A, Harmon K, Woodall J, Vieira A. Sports medicine applications of platelet rich plasma. Curr Pharm Biotechnol. 2012;13(7):1185-95.

5. Sheth U, Simunovic N, Klein G, Fu F, Einhorn TA, Schemitsch E, Ayeni OR, Bhandari M. Efficacy of autologous platelet-rich plasma use for orthopaedic indications: a meta-analysis. J Bone Joint Surg Am. 2012;94(4):298-307.

6. Eren G, Gurkan A, Atmaca H, Donmez A, Atilla G. Effect of centrifugation time on growth factor and MMP release of an experimental platelet-rich fibrin-type product. Platelets. 2016;27(5):427-32.

7. Sanchez M, Anitua E, Delgado D, Sanchez P, Prado R, Orive G, Padilla S. Plateletrich plasma, a source of autologous growth factors and biomimetic scaffold for peripheral nerve regeneration. Expert Opin Biol Ther. 2017;17(2):197-212.
8. Oliva F, Piccirilli E, Bossa M, Via AG, Colombo A, Chillemi C, Gasparre G, Pellicciari L, Franceschetti E, Rugiero C, Scialdoni A, Vittadini F, Brancaccio P, Creta D, Buono AD, Garofalo R, Franceschi F, Frizziero A, Mahmoud A, Merolla G, Nicoletti S, Spoliti M, Osti L, Padulo J, Portinaro N, Tajana G, Castagna A, Foti C, Masiero S, Porcellini G, Tarantino U, Maffulli N. I.S.Mu.L.T - Rotator Cuff Tears Guidelines. Muscles Ligaments Tendons J. 2016;5(4):227-63.

9. Holtby R, Christakis M, Maman E, MacDermid JC, Dwyer T, Athwal GS, Faber K, Theodoropoulos J, Woodhouse LJ, Razmjou H. Impact of platelet-rich plasma on arthroscopic repair of small- to medium-sized rotator cuff tears: a randomized controlled trial. Orthop J Sports Med. 2016;4(9): 2325967116665595.

10. Pandey V, Bandi A, Madi S, Agarwal L, Acharya KK, Maddukuri S, Sambhaji C, Willems WJ. Does application of moderately concentrated platelet-rich plasma improve clinical and structural outcome after arthroscopic repair of medium-sized to large rotator cuff tear? A randomized controlled trial. J Shoulder Elb Surg. 2016;25(8):1312-22.

11. Randelli PS, Arrigoni P, Cabitza P, Volpi P, Maffulli N. Autologous platelet rich plasma for arthroscopic rotator cuff repair. A pilot study. Disabil Rehabil. 2008;30(20-22):1584-9.

12. Bergeson AG, Tashjian RZ, Greis PE, Crim J, Stoddard GJ, Burks RT. Effects of platelet-rich fibrin matrix on repair integrity of at-risk rotator cuff tears. Am J Sports Med. 2012;40(2):286-93.

13. Jo CH, Kim JE, Yoon KS, Lee JH, Kang SB, Lee JH, Han HS, Rhee SH, Shin S. Does platelet-rich plasma accelerate recovery after rotator cuff repair? A prospective cohort study. Am J Sports Med. 2011;39(10):2082-90.

14. Barber FA, Hrnack SA, Snyder SJ, Hapa O. Rotator cuff repair healing influenced by platelet-rich plasma construct augmentation. Arthroscopy. 2011;27(8):1029-35.

15. Cai YZ, Zhang C, Lin XJ. Response to "efficacy of platelet-rich plasma in arthroscopic repair of full-thickness rotator cuff tears: a meta-analysis". J Shoulder Elb Surg. 2016;25(8):e248.

16. Li X, Xu CP, Hou YL, Song JQ, Cui Z, Yu B. Are platelet concentrates an ideal biomaterial for arthroscopic rotator cuff repair? A meta-analysis of randomized controlled trials. Arthroscopy. 2014;30(11):1483-90.

17. Warth RJ, Dornan GJ, James EW, Horan MP, Millett PJ. Clinical and structural outcomes after arthroscopic repair of full-thickness rotator cuff tears with and without platelet-rich product supplementation: a meta-analysis and meta-regression. Arthroscopy. 2015;31(2):306-20.

18. Zhang Q, Ge H, Zhou J, Cheng B. Are platelet-rich products necessary during the arthroscopic repair of full-thickness rotator cuff tears: a metaanalysis. PLoS One. 2013;8(7):e69731.

19. Zhao JG, Zhao L, Jiang YX, Wang ZL, Wang J, Zhang P. Platelet-rich plasma in arthroscopic rotator cuff repair: a meta-analysis of randomized controlled trials. Arthroscopy. 2015;31(1):125-35.

20. Higgins JP, Altman DG, Gotzsche PC, Juni P, Moher D, Oxman AD, Savovic J, Schulz KF, Weeks L, Sterne JA. The Cochrane Collaboration's tool for assessing risk of bias in randomised trials. BMJ. 2011;343:d5928.

21. Crouse C. Power to the PACU nurse: a primer for the beginner. J Post Anesth Nurs. 1987;2(4):274-5.

22. Santana TA, Trufelli DC, Matos LL, Cruz FM, Del Giglio A. Meta-analysis of adjunctive non-NK1 receptor antagonist medications for the control of acute and delayed chemotherapy-induced nausea and vomiting. Support Care Cancer. 2015:23(1):213-22.

23. Moskal JT, Capps SG. Is limited incision better than standard total hip arthroplasty? A meta-analysis. Clin Orthop Relat Res. 2013;471(4):1283-94.

24. Antuna S, Barco R, Martinez Diez JM, Sanchez Marquez JM. Plateletrich fibrin in arthroscopic repair of massive rotator cuff tears: a prospective randomized pilot clinical trial. Acta Orthop Belg. 2013; 79(1):25-30.

25. Castricini R, Longo UG, De Benedetto M, Panfoli N, Pirani P, Zini R, Maffulli N, Denaro V. Platelet-rich plasma augmentation for arthroscopic rotator cuff repair: a randomized controlled trial. Am J Sports Med. 2011;39(2):258-65.

26. Flury M, Rickenbacher D, Schwyzer HK, Jung C, Schneider MM, Stahnke K, Goldhahn J, Audige L. Does pure platelet-rich plasma affect postoperative clinical outcomes after arthroscopic rotator cuff repair? A randomized controlled trial. Am J Sports Med. 2016;44(8):2136-46.

27. Gumina S, Campagna V, Ferrazza G, Giannicola G, Fratalocchi F, Milani A Postacchini F. Use of platelet-leukocyte membrane in arthroscopic repair of large rotator cuff tears: a prospective randomized study. J Bone Joint Surg Am. 2012;94(15):1345-52. 
28. Jo CH, Shin JS, Lee YG, Shin WH, Kim H, Lee SY, Yoon KS, Shin S. Platelet-rich plasma for arthroscopic repair of large to massive rotator cuff tears: a randomized, single-blind, parallel-group trial. Am J Sports Med. 2013;41(10):2240-8.

29. Jo CH, Shin JS, Shin WH, Lee SY, Yoon KS, Shin S. Corrigendum. Platelet-rich plasma for arthroscopic repair of medium to large rotator cuff tears: a randomized controlled trial. Am J Sports Med. 2016:44(1):Np3.

30. Malavolta EA, Gracitelli ME, Ferreira Neto AA, Assuncao JH, BordaloRodrigues M, de Camargo OP. Platelet-rich plasma in rotator cuff repair: a prospective randomized study. Am J Sports Med. 2014;42(10): 2446-54.

31. Randelli P, Arrigoni P, Ragone V, Aliprandi A, Cabitza P. Platelet rich plasma in arthroscopic rotator cuff repair: a prospective RCT study, 2-year follow-up. J Shoulder Elb Surg. 2011;20(4):518-28.

32. Rodeo SA, Delos D, Williams RJ, Adler RS, Pearle A, Warren RF. The effect of platelet-rich fibrin matrix on rotator cuff tendon healing: a prospective, randomized clinical study. Am J Sports Med. 2012;40(6):1234-41.

33. Ruiz-Moneo P, Molano-Munoz J, Prieto E, Algorta J. Plasma rich in growth factors in arthroscopic rotator cuff repair: a randomized, double-blind, controlled clinical trial. Arthroscopy. 2013;29(1):2-9.

34. Márquez JMS, Díez JMM, Barco R, Antuña S. Functional results after arthroscopic repair of massive rotator cuff tears; influence of the application platelet-rich plasma combined with fibrin. Revista española de cirugía ortopédica y traumatología (English edition). 2011;55(4):282-7.

35. Weber SC, Kauffman Jl, Parise C, Weber SJ, Katz SD. Platelet-rich fibrin matrix in the management of arthroscopic repair of the rotator cuff: a prospective, randomized, double-blinded study. Am J Sports Med. 2013;41(2):263-70.

36. Jaeger M, Berndt T, Ruhmann O, Lerch S. Patients with impingement syndrome with and without rotator cuff tears do well 20 years after arthroscopic subacromial decompression. Arthroscopy. 2016;32(3):409-15.

37. McElvany MD, McGoldrick E, Gee AO, Neradilek MB, Matsen FA 3rd. Rotator cuff repair: published evidence on factors associated with repair integrity and clinical outcome. Am J Sports Med. 2015;43(2):491-500.

38. Park SE, Panchal K, Jeong JJ, Kim YY, Kim JH, Lee JY, Ji JH. Intratendinous rotator cuff tears: prevalence and clinical and radiological outcomes of arthroscopically confirmed intratendinous tears at midterm follow-up. Am J Sports Med. 2015;43(2):415-22.

39. Namdari S, Donegan RP, Chamberlain AM, Galatz LM, Yamaguchi K, Keener JD. Factors affecting outcome after structural failure of repaired rotator cuff tears. J Bone Joint Surg Am. 2014;96(2):99-105.

40. Barber FA. Platelet-rich plasma for rotator cuff repair. Sports Med Arthrosc Rev. 2013;21(4):199-205.

41. Mlynarek RA, Kuhn AW, Bedi A. Platelet-rich plasma (PRP) in orthopedic sports medicine. Am J Orthop (Belle Mead NJ). 2016;45(5):290-326.

42. Andia I, Maffulli N. Use of platelet-rich plasma for patellar tendon and medial collateral ligament injuries: best current clinical practice. J Knee Surg. 2015;28(1):11-8.

43. Gormeli G, Karakaplan M, Gormeli CA, Sarikaya B, Elmali N, Ersoy Y. Clinical effects of platelet-rich plasma and hyaluronic acid as an additional therapy for talar osteochondral lesions treated with microfracture surgery: a prospective randomized clinical trial. Foot Ankle Int. 2015;36(8):891-900.

44. Malhotra R, Kumar V, Garg B, Singh R, Jain V, Coshic P, Chatterjee K. Role of autologous platelet-rich plasma in treatment of long-bone nonunions: a prospective study. Musculoskelet Surg. 2015;99(3):243-8.

45. Pocaterra A, Caruso S, Bernardi S, Scagnoli L, Continenza MA, Gatto R. Effectiveness of platelet-rich plasma as an adjunctive material to bone graft: a systematic review and meta-analysis of randomized controlled clinical trials. Int J Oral Maxillofac Surg. 2016;45(8):1027-34.

46. Taylor DW, Petrera M, Hendry M, Theodoropoulos JS. A systematic review of the use of platelet-rich plasma in sports medicine as a new treatment for tendon and ligament injuries. Clin J Sport Med. 2011;21(4):344-52.

47. Zhou Q, Xu C, Cheng X, Liu Y, Yue M, Hu M, Luo D, Niu Y, Ouyang H, Ji J, et al. Platelets promote cartilage repair and chondrocyte proliferation via ADP in a rodent model of osteoarthritis. Platelets. 2016;27(3):212-22.

48. Laver L, Carmont MR, McConkey MO, Palmanovich E, Yaacobi E, Mann G, Nyska M, Kots E, Mei-Dan O. Plasma rich in growth factors (PRGF) as a treatment for high ankle sprain in elite athletes: a randomized control trial. Knee Surg Sports Traumatol Arthrosc. 2015;23(11):3383-92.

49. Mussano F, Genova T, Munaron L, Petrillo S, Erovigni F, Carossa S. Cytokine, chemokine, and growth factor profile of platelet-rich plasma. Platelets. 2016; 27(5):467-71.
50. Alsousou J, Thompson M, Hulley P, Noble A, Willett K. The biology of platelet-rich plasma and its application in trauma and orthopaedic surgery: a review of the literature. J Bone Joint Surg Br. 2009;91(8):987-96.

51. Magalon J, Bausset O, Serratrice N, Giraudo L, Aboudou H, Veran J, Magalon G, Dignat-Georges F, Sabatier F. Characterization and comparison of 5 platelet-rich plasma preparations in a single-donor model. Arthroscopy. 2014;30(5):629-38.

52. Smyth NA, Murawski CD, Fortier LA, Cole BJ, Kennedy JG. Platelet-rich plasma in the pathologic processes of cartilage: review of basic science evidence. Arthroscopy. 2013;29(8):1399-409.

53. Beck J, Evans D, Tonino PM, Yong S, Callaci JJ. The biomechanical and histologic effects of platelet-rich plasma on rat rotator cuff repairs. Am J Sports Med. 2012;40(9):2037-44.

54. Ersen A, Demirhan M, Atalar AC, Kapicioglu M, Baysal G. Platelet-rich plasma for enhancing surgical rotator cuff repair: evaluation and comparison of two application methods in a rat model. Arch Orthop Trauma Surg. 2014;134(3): 405-11.

55. Hapa O, Cakici H, Kukner A, Aygun H, Sarkalan N, Baysal G. Effect of plateletrich plasma on tendon-to-bone healing after rotator cuff repair in rats: an in vivo experimental study. Acta Orthop Traumatol Turc. 2012;46(4):301-7.

56. Cai YZ, Zhang C, Lin XJ. Efficacy of platelet-rich plasma in arthroscopic repair of full-thickness rotator cuff tears: a meta-analysis. J Shoulder Elb Surg. 2015;24(12):1852-9.

57. Fu CJ, Sun JB, Bi ZG, Wang XM, Yang CL. Evaluation of platelet-rich plasma and fibrin matrix to assist in healing and repair of rotator cuff injuries: a systematic review and meta-analysis. Clin Rehabil. 2017;31(2):158-72.

58. Chahal J, Van Thiel GS, Mall N, Heard W, Bach BR, Cole BJ, Nicholson GP, Verma NN, Whelan DB, Romeo AA. The role of platelet-rich plasma in arthroscopic rotator cuff repair: a systematic review with quantitative synthesis. Arthroscopy. 2012;28(11):1718-27.

\section{Publisher's Note}

Springer Nature remains neutral with regard to jurisdictional claims in published maps and institutional affiliations.

Ready to submit your research? Choose BMC and benefit from:

- fast, convenient online submission

- thorough peer review by experienced researchers in your field

- rapid publication on acceptance

- support for research data, including large and complex data types

- gold Open Access which fosters wider collaboration and increased citations

- maximum visibility for your research: over $100 \mathrm{M}$ website views per year

At $\mathrm{BMC}$, research is always in progress.

Learn more biomedcentral.com/submissions 